\title{
MODEL DEVELOPMENT STRATEGY LEARNING 5MT (SQRACT) DIMENSIONS BASED PROCESS FOR ENHANCING COGNITIVE ABILITY TO READ THE SCIENTIFIC DISCOURSE UNDERSTANDING CLASS X SENIOR HIGH SCHOOL
}

\author{
Rina Andriani ${ }^{1}$, Yeti Mulyati ${ }^{2}$ \\ ${ }^{1,2}$ Universitas Bale Bandung, Kabupaten Bandung \\ rinawijaya13@yahoo.com
}

\begin{abstract}
This study aims to develop and test the effectiveness of the strategy learning model 5MT (mengamati, menanya, membaca, menalar, mengomunikasikan, tes) (SQRACT= survey, question, read, association, communicating, test)) based on the dimension of the cognitive processes to improve reading comprehension of scientific discourse. The study was conducted using the method Reseacrh \& Development, includes three phases: the planning, the development, and implementation stages. The implementation results showed among a control group with the experimental group, there is a significant difference of $0.005<0.05$. While learning to read when they see the results of scientific discourse understanding gained significant difference of $0.009<0.05$ between who have high scientific attitude and students who have low scientific attitude, and if the relationship between reading comprehension of scientific discourse with a scientific attitude is not there a significant relationship $0.985>0.05$. Thus the authors can improve reading comprehension while enhancing the ability to think of High Order Thinking class X SMAN Ciparay Bandung regency in the academic year 2015/2016
\end{abstract}

Keywords: Model Development, Strategy 5MT (SQRACT), Cognitive Process Dimension, Ability Reading Comprehension, Scientific Discourse

\section{INTRODUCTION}

In this 21 st century, students face a variety of risks and uncertainties in line with the development environment so rapidly, such as technology, science, economics and socioculture, so that students are required to learn more and be proactive so that they have the knowledge and skills / expertise adequate. This situation demands the teacher as the spearhead in the forefront of education is able to provide the knowledge, attitudes, behaviors, and skills through learning strategies and patterns that correspond to the demands and development is in accordance disclosed Mendikbud 26-28 June 2013 that century 21 is the age of information, computing, automation, and communication.

Damaianti (2008, page v) suggests the presence of global era of information plays a very important cause. In almost all industrialized countries of skilled people absorb and digest the information flowing. Among the various information media, the print media is media that has its own advantages. By reading the print media people do not stop in the quest for information, but he was involved in a mental activity. When reading, the linking of the basic concepts have been held with the new information from the text read. Thus, people can master 
the information is good and this is a valuable investment. Therefore, the ability to read important high possessed by each person.

Reading is not the only activity stared written symbols alone, but a variety of capabilities deployed by a reader to be able to understand the material being read. The symbols of the sounds of language should be changed into symbols of writing, decoding process (cryptanalysis) and recording (encoding back) is what should continue to be developed and controlled by a reader. An aspect of cryptanalysis (decoding) is the process of connecting the write words (written word) with the meaning of spoken language (oral language meaning) that includes the conversion of paper / print into sound meaningful. (Anderson 1972: pp. 209210).

The results of PISA (Programme for International Student Assessment) in 2000 showed that students' reading literacy Indonesia classified low compared with students their own age in foreign countries. Of the 41 countries surveyed, Indonesian students was ranked 39th with an average value of 371, slightly above Albania (349) and Peru (327). The ability of our students is still far below the student Thailand (ranked 32 with a value of 431) but closer to the students Macedonia (373) and Brazil (396).

The results of these studies are not exaggerated, the reality of Indonesian students for six (6) levels of literacy and incorporating one or more information either concerned or opposed more than $50 \%$ are at level 2, while the ability to interpret and integrate information ranked 56 th out of 65 countries and to integrate and interpret information more than $50 \%$ below the level 2. in the August 2016 edition of Kompas daily written: UNESCO report on tahun2012 upon ability to read European children a year spent an average of 25 books, while Indonesia reached the lowest point: $0 \%$ !, exactly 0.001 percent. That is, of 1,000 children Indonesia, only one child was able to spend one book a year.

Reading comprehension is an activity carried out by someone with the intention of capturing the content or the meaning contained in the discourse in depth, whole and complete. Bertemali with reading comprehension Lado (1964: p 132) argues that read as "... grap pattern from their written language representation," meaning that reading is an activity to understand the patterns of language are unpresentable in writing. In this case means reading is regarded as an activity of reconstructing the message, it means the act of reading involves the ability of sensory, perceptual, sequences, experience, thinking, learning, association, affective, and constructive. If all of these capabilities combined the reading activities will occur and will acquire meaning.

Based on the reality of the importance, 1) reading comprehension in the study of scientific discourse and 2) improve the ability to think logically, trace, and systematic student to a level higher level thinking (High Order Thinking / HOT) through questions on the easy level to complex, namely $\mathrm{C} 1, \mathrm{C} 2, \mathrm{C} 3, \mathrm{C} 4, \mathrm{C} 5$ to $\mathrm{C} 6$ and 3) the influence of the scientific attitude of students toward success in learning reading comprehension, the author deems it necessary to do research sekaitan with it. Therefore, the authors conducted a study entitled "Development Strategy 5MT (SQRACT) Based Cognitive Process Dimension for Increasing Reading Comprehension Ability of Scientific Discourse". Implementation of the strategy is expected to improve reading comprehension of students in the learning process of scientific discourse. 


\section{Reseacrh Problem}

The following reasearch problems, how is the effectiveness of the strategy 5MT (SQRACT) based Cognitive Process Dimension in improving reading comprehension of scientific discourse student in grade X SMAN Ciparay Bandung disctrict in the academic year $2015 / 2016$ ?

\section{Theoretical Framework Strategy5MT (SQRACT)}

Strategy 5MT (SQRACT) is a strategy that has criteria based learning in science learning steps at once to the facts or phenomena that can be explained by logic or reasoning by implementing the strategy of learning tertentu..Process 5 MT (SQRACT) should be guided by scientific principles, This strategy is characterized by protrusion dimension of observation, reason, invention, information gathering, validating, and explanations and make conclusions about a truth at once tested the ability of the self by creating or producing some object or new information. Thus the learning process should be carried out with guided the values,principles, orscientificcriteria

The concept of learning is developing now focused on constructive learning is meaningful learning means a process of active, cognitive and constructive learning. Students in the learning process brings extensive knowledge, purpose, and their own experience and use it to "understand" the information that they have encountered. Constructive process "understand" this dig previous knowledge and includes a variety of cognitive processes that work on such knowledge. (Krathwohl, 2010).

Cognitive Process Dimension proposed by Anderson and Krathwohl (2010: p. 99) includes: 1) given (to recognize and recall), 2) understanding, 3) apply, 4) analyze), 5) evaluating, 6) create Reading comprehension is a skill that is the reading comprehension (comprehension skills) includes aspects comprehend simple terms (lexical, grammatical, rhetorical), understand the significance or meaning (purpose and objective of the authors, relevance or circumstances, and the reaction of the reader), evaluation or assessment includes the contents and shape, speed reading is flexible, easily adapted to the circumstances.

\section{Reseacrh Model and Methodogy}

This study was designed to develop and test the effectiveness of the strategy 5MT (SQRACT) based on the dimensions of the cognitive processes to increase reading comprehension scientific discourse tenth graders of high school, In connection with that purpose, study design was designed by the Research and Development ( $\&$ D) by way of to develop new products or enhance a product that has ada.The implementation of research and development, there are several methods that I use to refer to the opinions Sukmadinata (20005, hlm.167): stage descriptive, evaluative, and experiment.

\section{Data Analysis}

Data was analyzed using an interactive model, which analyzes data through four (4) components of the analysis: data reduction, data presentation, drawing conclusions, and verification. The fourth component is done simultaneously (Miles, 1988). 


\section{RESULT AND DISCUSSION}

\section{Description of Performance Capabilities Scientific Discourse Reading Comprehension}

1. Frequency and Percentage of Text Discourse Reading Comprehension Ability Scientific

a. Pretest and post-test comparisons Controls Class I

\section{Histogram 5.1}

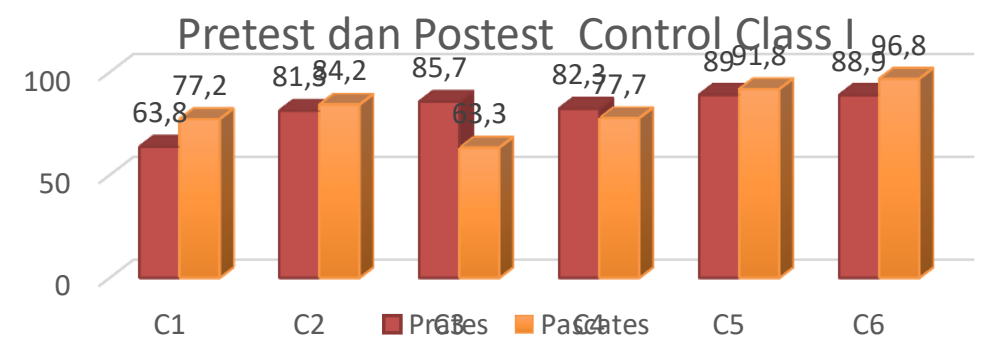

The histogram above shows that there is an increase at every level of cognitive, except at the level of cognitive C3 (applying) and C4 (analyzing). The increase was relatively small percentage.

\section{Histogram 5.2}

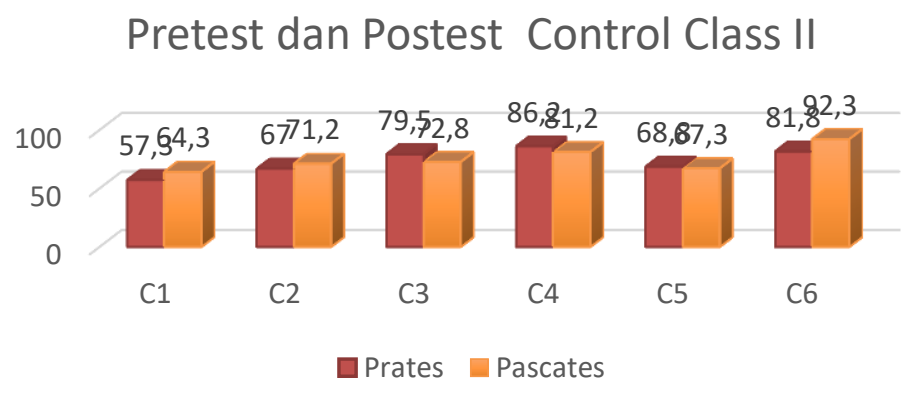

The histogram above shows that there is an increase and decrease at every level of cognition. The increase occurred in the $\mathrm{C} 1$ level (remembering), C2 (understanding), and C6 (creating), while the level of cognitive decline occurs in C3 (applying), C4 (analyzing) and C5 (evaluating). The annual rise relatively small percentage.

2. Frequency and Percentage of Text Discourse Reading Comprehension Ability Scientific

a. Prates and post-test comparisons Experiment Class I

\section{Histogram 5.3}

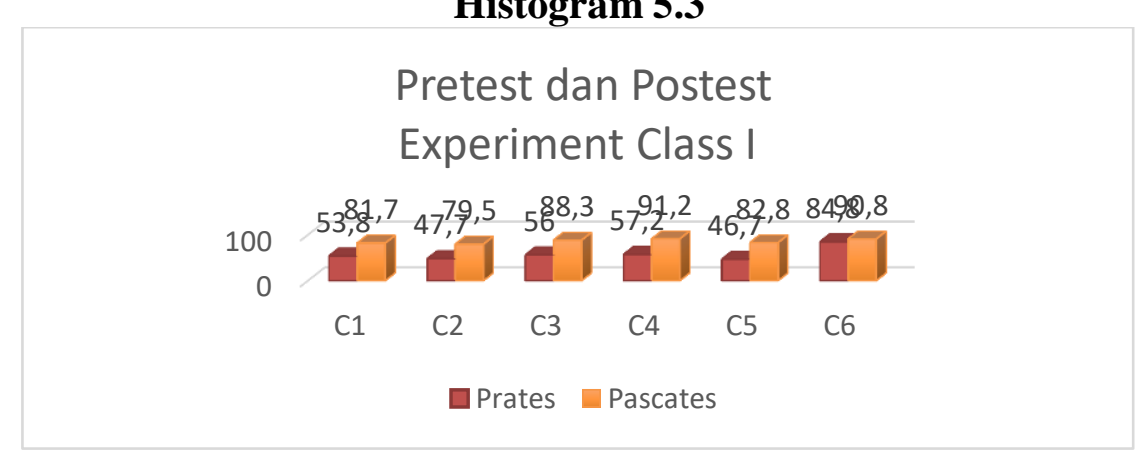

The histogram above shows an increase at every level of the cognitive and the increase percentage is relatively high percentage. 
b. Prates and post-test comparisons Class Experiment II

Histogram 5.4

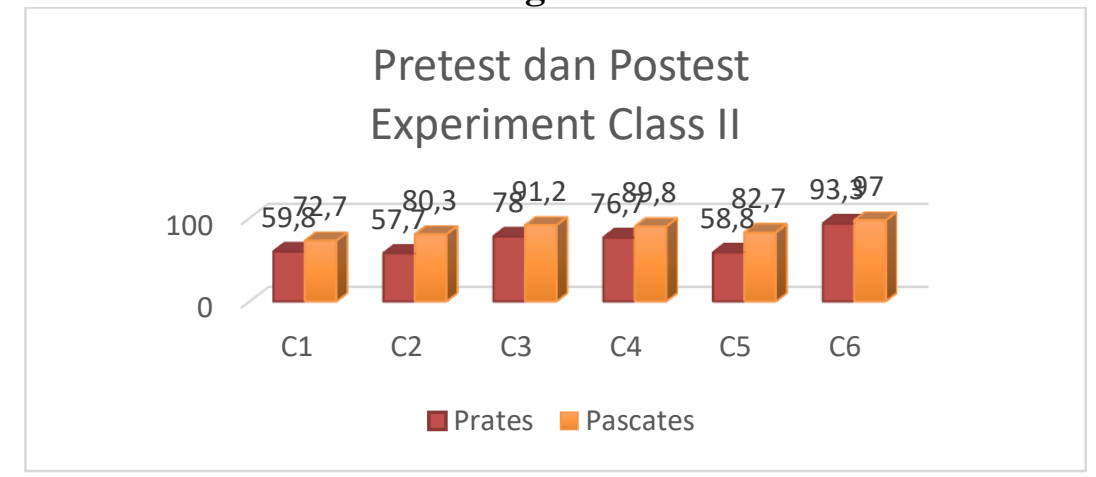

The histogram above shows an increase at every level of the cognitive and the increase percentage is relatively high.

Discussion of Preliminary Test Results (Prates) and Final Test (post-test) Ability of Scientific Discourse Reading Comprehension Strategies Using 5MT (SQRACT) Based CognitiveProcessDimension

The effectiveness Strategy 5MT (SQRACT) Based Cognitive Process Dimension For Upgrades Scientific Discourse Reading Comprehension Class X, from the comparison of the pre-test (before treatment) and post (after treatment) in the experimental class showed that there was an increase at every level of the cognitive and the increase percentage is relatively high. This means that this strategy is able to explore and optimize the advanced thinking abilities of students even tend to be dug on the level of cognitive requires the ability to think critically these are, C2 (understand), C3 (applying), C4 (analyze), C5 (evaluate) and C6 (create).

\section{CONCLUSION AND SUGGESTION REFERENCES}

\section{Conclusion}

Strategies 5MT (SQRACT) based dimension of cognitive processes in High School District Bandung effectively improve students' reading comprehension of scientific discourse, it is seen from the data processing there is a significant value for the treatment of $0.005<0.05$, meaning there is a difference learning outcomes reading comprehension significant scientific discourse between the control group who did not use the strategy 5MT (SQRACT) based on the dimensions of cognitive processes with an experimental group that used the strategy 5MT (SQRACT) -based dimension of cognitive processes..Strategi 5MT (SQRACT) based dimension of cognitive processes effectively while improving thinking skills level (high order thinking) class X student high school.

\section{Suggestion References}

Government as a stakeholder in the implementation of education not only as implementers but also should be a mediator, fasailitator, motivator for teachers to develop their ability, especially in the choice of methods, techniques, or learning strategies so that more optimal learning outcomes. 


\section{REFERENCES}

Abidin, Y. (2014). Desain sistem pembelajaran dalam konteks kurikulum 2013. Bandung: Refika Aditama.

Al-Jamal, Dira, Mahir Al-Hawamleh, \& Ghadeer Al-Jamal. (2013). An assessment of reading comprehension practice in Jordan. Jordan journal of Educational Scienes. Vol. 9. No. 3, pp-335-344. (pdf) journals.yu.edu.jo/jjes/issues/2013/.../7.pdf.

Anderson, LW. dan Kratwohl, DR. (2010). Kerangka landasan untuk pembelajaran, pengajaran, dan assesmen (Revisi taksonomi pendidikan Bloom). Yogyakarta: Pustaka Pelajar.

Arikunto, S. (2002). Prosedur penelitian suatu pendekatan praktek. Edisi Revisi V. Jakarta: Rineka Cipta

Baldridge, KP. (1979). The seven reading strategies. Connecticut: Baldrige Reading Instruction Materials. Inc.

Carin, A. \& Sund, R.B. (1971). Developing questioning techniques. Columbus Ohio: Charles E. Merril Publishing.

Creswell, JW. (2002) Research design. Jakarta: Klik Press.

Dahar, R.W. (1996). Teori-teori belajar. Jakarta: Erlangga.

Dahar, R.W. (1992). Dampak pertanyaan dan teknik bertanya guru selama proses belajar mengajar IPA pada berpikir siswa. Bandung: FMIPA IKIP Bandung.

Daryanto. (2014). Pendekatan pembelajaran saintifik kurikulum 2013. Yogyakarta: Gava Media.

De Bono, E. (1990). Mengajar berpikir. Alih Bahasa. Soemardjono. Jakarta: Erlangga.

Umum.

Duke, Nell K. \& P. David Pearson. (2002). Effective practices for developing reading comprehension.Scholastic RED. Professional Article. From: What Reasearch Has to Say About Reading. Third Edition. Copyright@2002 by the International Reading Association. Inc. www.ps23r.org/download.ayd/file...89d4...

ejournal-undiskha.ac.id/index.php/JJGSD/article/viewfile/859/731—PQRST—8.

Flood, J. (1984) Understanding reading comprehension: cognition, language, and the structure of prose.Delaware 19714. International Reading Association.

Fraenkel dan Wallen. (Fraenkel). How to Design and Evaluate Research in Education.Amerika. McGraw-Hill Higher Education.

Harjasujana, A.S. \& Damaianti, VS. (2003). Membaca dalam teori dan praktik. Bandung: Mutiara.

Hosnan, M. (2014). Pendekatan saintifik dan kontekstual dalam pembelajaran abad 21. Bogor: Ghalia Indonesia.

https://ww.google.co.id/?gws_rd=ssi\#q=jurnal+tentang+SQ3R (12 Oktober 2015).

https://www.unige.ch/fapse/logopedie/files/2814/1285/1038/cain-article \& bis.pdf ESRC, Economic \& Social Research Council. Reading Comprehension: Nature, Assesment, and Teaching. (7 Januari 2016)

https://www.questia.com/...journal/.../a.reading. Reading Comprehension Strategy Using The Discourse of Science.(7 Januari 2016).

Joyce, B \& Weil, M. (1980). Models of teaching. New Jersey: Prentice-Hall, Inc.

Klein, ML., etc. (1991). Teaching reading in the elementary grades. Annonated instructors edition.United States of america: A Division of Simon \& Schuster, Inc.

Kuswana, WS. (2012). Taksonomi kognitif. Bandung. PT Remaja Rosdakarya. 